\title{
Technology Integration into the Teaching and Learning of Geography in Senior High Schools in Ghana: A TPACK Assessment
}

\author{
Bismark Mensah", Adjoa Afriyie Poku, Augustine Yao Quashigah \\ Department of Geography Education, University of Education, Winneba, P. O. Box 25, Winneba, Ghana \\ E-mail: bismarkmensah@uew.edu.gh
}

Received: 25 October 2021; Revised: 25 November 2021; Accepted: 14 December 2021

\begin{abstract}
In Ghana, the integration of technology into the teaching and learning process seems to be making strides in tertiary education. However, the case is not the same in Senior High Schools. This study, therefore, sought to assess Senior High School Geography teachers' knowledge in integrating technology into their classroom adapting the Technological Pedagogical Content Knowledge (TPACK) model as a framework for analysis. The study adopted the descriptive survey design to provide a comprehensive analysis of the research problem. Through a survey, a total of 113 geography teachers participated in the study, responding to a TPACK survey questionnaire. The data were analysed using mean and standard deviation. The findings of the study showed that teachers possessed a high level of content and pedagogical knowledge in geography. The analysis, however, showed that teachers were not as confident as they were in content and pedagogy compared to technological knowledge and its subsequent integration into the teaching and learning of geography. It was, therefore, recommended among others that courses at the higher education level should integrate Information and Communication Technologies (ICTs) into teaching and learning to help student-teachers appreciate the place of specific technologies, hardware and software in the teaching and learning of their respective disciplines.
\end{abstract}

Keywords: technology integration, teaching Geography, Technological Pedagogical Content Knowledge (TPACK), Senior High Schools, Ghana

\section{Introduction}

The role of technology in education in the twenty-first century cannot be overemphasized. Amedzo (2007) posits that the world has reached a stage where a person without basic computer knowledge finds it almost impossible to function properly in society. Technology generally conveys the idea of advancement, improvement, and progress, whereas the lack of technology stirs feelings towards practice as archaic, ineffective, and awkward (Earle, 2002). Voogt (2010) highlights that ICT enhances integrative learning through the transformation of theories into practice. In Ghana, one area of concern regarding the use of technology is the educational sector. This sector seems to be lagging behind when it comes to integrating technology into teaching and learning. The situation in the second-cycle institutions is alarming as technological devices are mostly unavailable or insufficient (Afari-Kumah \& Tanye, 2009). Improvement can, however, be seen at the tertiary level where "most universities are now moving away gradually from depending on lecture notes and textbooks only, to online courses and e-resources" (Afari-Kumah \& Tanye, 2009).

Copyright (C2021 Bismark Mensah, et al.

DOI: https://doi.org/10.37256/ser.3120221218

This is an open-access article distributed under a CC BY license

(Creative Commons Attribution 4.0 International License)

https://creativecommons.org/licenses/by/4.0/ 
The slow and almost non-integration of ICT into teaching and learning in Ghanaian Senior High Schools has been blamed on either inadequate or lack of proper ICT resources, poor expertise of teachers and unavailability of the desired ICT tools in schools (Boadu et al., 2014). Ghana's education policymakers have attempted to encourage the use of ICT in the classroom through educational reforms and other policies over the years, but these attempts seem to have lost their substance partly because of the aforementioned factors (Amenyedzi et al., 2011). A close look at the Senior High School level shows that apart from the introduction of ICT as a subject, most teachers do not infuse technology into their classroom instruction (Boadu et al., 2014; Ababio \& Dumba, 2014).

Despite the massive investment in the integration of ICT into many secondary schools, the practical use of these ICT tools by teachers remains in a preliminary stage with little significance in the educational outcome (Agyei, 2013). The incorporation of ICT into the teaching and learning of geography has been given little attention and investigation, especially in the Ghanaian context (Antwi et al., 2018; Boadu et al., 2014). Most studies have proven that geography teachers in Senior High Schools in Ghana focus mostly on the traditional methods of teaching the subject: lecture, discussion, fieldwork, project and questioning method (Kocalar \& Demirkaya, 2017; Ababio \& Dumba, 2014). It is important to iterate that integrating information technologies into the teaching and learning process goes beyond the availability of ICT tools in a school. The users of these tools must possess some facets of knowledge spelled out in the Technological Pedagogical Content Knowledge (TPACK) model (Mishra \& Koehler, 2006).

For instance, studies have shown that the mere presence of technology in the classroom does not guarantee its effective integration into the teaching and learning process, but rather, dependent on teachers' ability to repurpose the available tool to meet the needs of the learners (Kereluik et al., 2011; Mishra \& Koehler, 2006). For effective technology integration, teachers are expected to possess technological knowledge, technological content knowledge, technological pedagogical knowledge, and technological pedagogical content knowledge (Mishra \& Koehler, 2006).

Meanwhile, like many other subjects, it is difficult to teach certain topics in geography without the integration of information technology applications such as Google Earth, computer simulation programs, interactive compact discs, Global Positioning Systems (GPS) and Geographic Information Systems (GIS) among others (Geographical Association, 2004; Antwi et al., 2018). Some topics in geography, especially in physical geographies such as longitudes and latitudes, may appear abstract and difficult for students to relate to (Antwi et al., 2018). The use of technology helps remove abstraction from teaching and learning of all aspects of geography. It is, therefore, incumbent on geography teachers to be innovative in their teaching, making the subject more interesting and real, rather than a presentation of a mere collection of names of places and rivers and mountains, as others have perceived the discipline over the years (Opoku, 2019; Fatima, 2016).

In the light of this, using the TPACK model as a framework, the study assessed the extent to which geography teachers possess technological pedagogical content knowledge. Niess (2005) suggests that these aspects of TPACK research are worth probing since it provides the basis to predict whether teachers will be able to integrate information technologies into their teaching or not. Although the concept of teaching with technologies has been explored by several authors within the Ghanaian education landscape (Antwi et al., 2018; Afari-Kumah \& Tanye, 2009; Boadu et al., 2014; Ababio \& Dumba, 2014), less attention has been paid to assessing teachers' TPACK which is key to determine whether instructors will be able to integrate available technological resources into classroom teaching. It is against this background that the current study was carried out to assess teachers' technological pedagogical content knowledge in the teaching and learning of geography.

\section{Research questions}

The main purpose of the study was to measure geography teachers' TPACK in the teaching and learning of geography. To achieve this, the study sought to find answers to the following questions.

1. What is the level of teachers' rating of their understanding of technological content knowledge of geography?

2. What is the level of teachers' rating of their understanding of technological pedagogical knowledge of geography?

3. What is the level of teachers' rating of their understanding of technological pedagogical content knowledge of geography? 


\section{Technological pedagogical content knowledge model}

The TPACK framework (Koehler \& Mishra, 2008; Mishra \& Koehler, 2006) explains the types of knowledge teachers require in teaching effectively with technology. Koehler and Mishra (2005) assert that; "the basis of good teaching with technology requires an understanding of the representation using technologies; pedagogical techniques that use technologies in constructive ways to teach content; knowledge of what makes concepts difficult or easy to learn and how technology can help redress some of the problems that students face; knowledge of students' prior knowledge and theories of epistemology; and knowledge of how technologies can be used to build on existing knowledge and to develop new epistemologies or strengthen old ones (p. 1029). With the TPACK model, Mishra and Koehler (2006) explain the complex role of and the interplay between three essential elements in the teaching and learning environment: content, pedagogy and technology. In view of this, the TPACK model represents three main levels of teacher knowledge: content knowledge, pedagogical knowledge and technological knowledge. The overall intersection of these three levels of knowledge is what Koehler and Mishra (2005) referred to as technological, pedagogical content knowledge. In this study, the authors adapted the TPACK model by looking at three key constructs out of the seven proposed by Koehler and Mishra (2005). These included technological content knowledge, technological pedagogical knowledge and technological pedagogical content knowledge (see Figure 1). Emphasis was not placed on measuring content and pedagogical knowledge of the geography teachers because, in teacher training, as noted by Ababio and Dumba (2014), content and pedagogy are a primary set of prerequisites for teaching in Ghana. For instance, a study conducted by Boadu et al. (2014) revealed that most teachers possess adequate subject matter knowledge and knowledge of instructional techniques. However, what teachers seem to lack is the ability to both select specific technologies to teach certain contents (technological content knowledge) and integrate these technologies into instructional strategies (technological pedagogical knowledge) (Mereku et al., 2009).

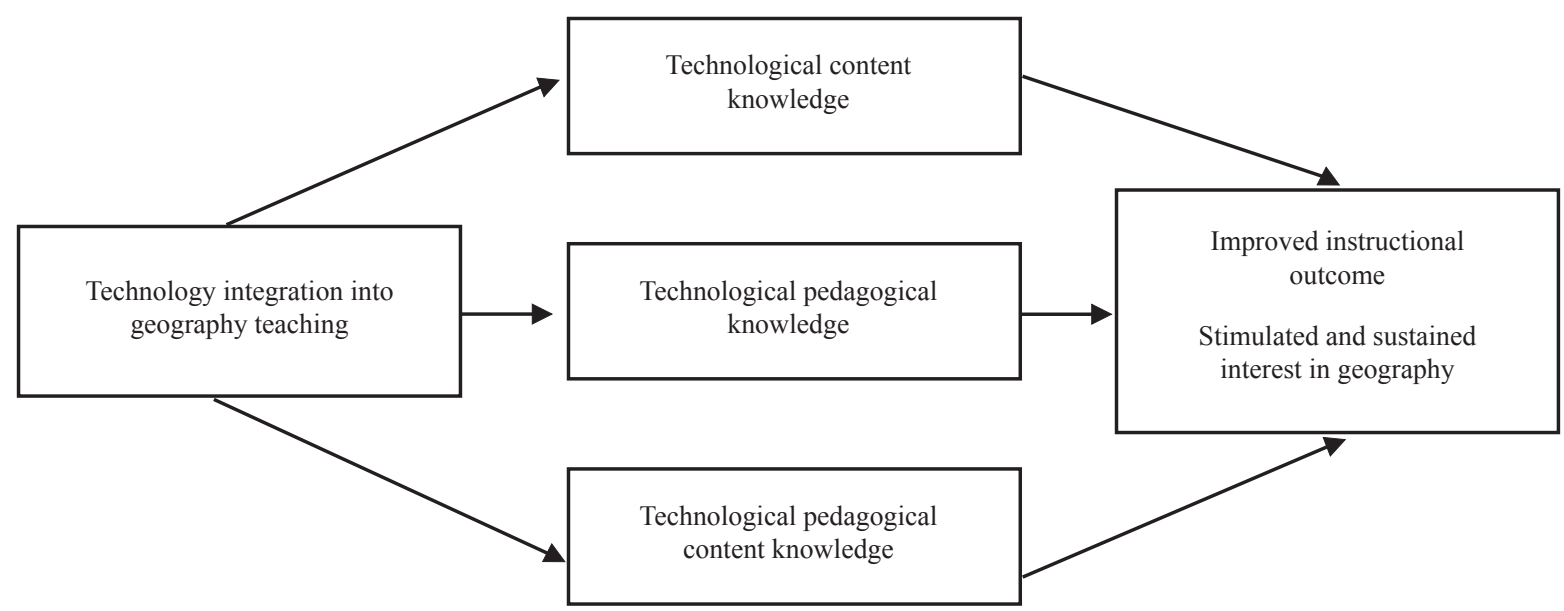

Source: Adapted from Koehler and Mishra’s (2005) TPACK model

Figure 1. Technology integration into teaching geography model

As shown in Figure 1, the ability of geography teachers to integrate technologies into their teaching is determined by the possession of technological content knowledge, technological pedagogical knowledge and technological pedagogical content knowledge. The net effects of employing such levels of knowledge in the classroom are improved instructional outcomes and stimulated and sustained interest in the learning of geography (Earle, 2002; Voogt, 2010).

\section{Methodology}

This study was carried out in senior high schools in the central region of Ghana. The study targeted all senior high 
school geography teachers within the central region of Ghana and adopted the descriptive survey design. According to data released by Ghana Education Fact Sheets (2020), there are seventy-six public senior high schools in the central region. Each of these schools is estimated to have three geography teachers to handle the physical, human and practical aspects of the discipline, giving a total of 228 teachers. The researchers made keen efforts to reach out to every senior high school geography teacher within the region using both face-to-face and online administrations of the questionnaire. However, after the six-month period of data collection, 113 teachers representing almost fifty percent (49.56\%) of the targeted population participated in the survey. The teachers responded to a TPACK survey instrument. A survey was used, because it enables a large sample size to be obtained for a study, thereby laying the foundation for valid generalizations (Gray, 2004); helps describe the nature of an existing phenomenon (Cohen et al., 2007); helps obtain information about attitudes which are difficult to measure using observation (McIntyre, 1999); and finally, has the strength to provide all respondents with a standardised stimulus and reduce biases of the researcher (Sarantakos, 2013).

The TPACK survey questionnaire used for the study was adapted from Su et al. (2017). The reason for adapting the survey questionnaire was that their study focused primarily on developing an appropriate instrument for assessing the TPACK of geography teachers in senior high schools. Items on the questionnaire were organised into four sections. The first section consisted of items that solicited data on respondents' demographic characteristics as captured in Table 1. The remaining three sections were based on the constructs under study: Technological Pedagogical Knowledge (TPK), Technological Content Knowledge (TCK), and Technological Pedagogical Content Knowledge (TPACK). Specifically, TPK had seven (7) items, TCK had four (4) items, and TPACK had five (5) items. For each item under the respective construct, teachers rated themselves based on a Likert scale with 5 points intervals ranging from "strongly disagree" to "strongly agree". The Cronbach's alpha reliability was used to determine the reliability of the items under each construct. The reliability test conducted using Statistical Package for the Social Sciences (SPSS) showed alpha values between 0.79 and 0.91 . A reliability coefficient (alpha) of 0.70 or higher is considered acceptable reliability in SPSS (Bolarinwa, 2015). The study was purely quantitative as the researchers sought to measure the facets of knowledge geography teachers possessed to be able to successfully integrate technologies into their teaching (Mishra \& Koehler, 2006). The responses generated from the survey questionnaire were analysed using SPSS version 21.0. Descriptive statistics such as mean and standard deviation were used to present the results.

Table 1. Demographic characteristics of respondents

\begin{tabular}{cccc}
\hline Item & Responses & Frequency & Percentage \\
\hline Gender & Male & 78 & 69.03 \\
& Female & 35 & 30.97 \\
Age group & $20-24$ & 13 & 11.50 \\
& $25-29$ & 80 & 70.80 \\
& $30-34$ & 6 & 5.30 \\
Years of teaching experience & $35-39$ & 2 & 1.80 \\
& Above 40 & 12 & 10.60 \\
Highest qualification & $1-5$ & 87 & 77.00 \\
& $6-10$ & 13 & 11.50 \\
& Above 10 & 13 & 11.50 \\
& Bachelor's degree & 98 & 86.73 \\
\hline
\end{tabular}

Source: Field data (2020) 
The researchers ensured that ethical issues were also properly addressed by collecting data devoid of personal identifiers like names and national identification numbers. Thus, the confidentiality of data and anonymity of respondents were values upheld by the researchers.

\section{Results}

\subsection{Geography teachers' rating of their understanding of technological content knowledge}

The TCK construct of the TPACK model seeks to evaluate teacher knowledge about specific technologies, whether traditional or modern, that could be used in delivering certain aspects of the subject matter. It is interesting to notice that the general mean scores for all the items under the TCK construct were below 4.0, indicating that the teachers were not very competent in using technology to deliver certain aspects of the subject matter. Table 2 captures the mean scores of geography teachers' TCK.

Table 2. Technological Content Knowledge of geography teachers

\begin{tabular}{ccc}
\hline Statement & Mean & SD \\
\hline I can use geography-specific software tools such as Google Earth, GPS, etc. \\
to demonstrate geography subject content \\
I know what information technologies can be applied to teach geography & 3.86 \\
I can use proper information technologies to represent geography subject content & 3.65 & 1.23 \\
I can use geography-specific software to conduct geography-related inquiry activities & 3.58 & 1.29 \\
\hline
\end{tabular}

Source: Field data (2020)

Table 2 shows that the dominant part $(\mathrm{M}=3.86, \mathrm{SD}=1.23)$ of the respondents indicated they can use geographyspecific software such as Google Earth and GPS to demonstrate geography subject content. This finding is heartwarming since using such tools makes geographical thinking more practical, bringing the spatial phenomena to a close view. The mean score for this item was also the highest among other items under the same construct. The dominant part $(\mathrm{M}=3.65, \mathrm{SD}=1.16)$ of the respondents indicated that they know what information technologies can be applied to teach geography. The teachers scored the same mean for the item "I can use proper information technologies such as multimedia resources to represent geography subject content". However, the spread of their responses was relatively wide compared to the former item ("I know what information technologies can be applied to teach geography"). This shows some level of disagreement among the teachers in terms of using appropriate information technologies to represent geography subject content.

The lowest mean score $(\mathrm{M}=3.58, \mathrm{SD}=1.16)$ under the TCK was recorded for the item "I can use geographyspecific software to conduct geography-related inquiry activities". This implies that geography teachers have some level of difficulty in using geography-specific software such as Google Earth, planetarium to undertake spatial inquiries.

\subsection{Geography teachers' rating of their understanding of Technological Pedagogical Knowledge (TPK)}

TPK basically sought to evaluate teachers' understanding of how technology can present both constraints and affordances to specific pedagogical practices. To achieve this, teachers were made to score themselves on a five-point scale ranging from "strongly disagree" to "strongly agree" based on a number of statements about TPK. The mean scores of teachers for the items under the TPK construct are summarised in Table 3. 
Table 3. Technological Pedagogical Knowledge of geography teachers

\begin{tabular}{ccc}
\hline Statement & Mean & SD \\
\hline I can choose appropriate information technologies to optimize geography teaching & 3.63 & 3.88 \\
I can utilize information technologies to improve classroom interaction & 4.35 & 1.05 \\
I can use information technologies to enhance students' enthusiasm for learning & 3.93 \\
I can use information technologies to engage students to & 3.99 \\
I see the use of information technologies in the classroom from a critical perspective & 3.93 \\
I can adaptively use information technologies in various teaching activities & 1.10 \\
I can select appropriate information technologies to optimize geography teaching \\
(such as using Google Earth to support the geographical inquiry)
\end{tabular}

Source: Field data (2020)

From Table 3, it is clear that teachers demonstrated some level of confidence in their ability to integrate their knowledge of technology into carrying out specific instructional strategies and methodologies. For example, the majority $(\mathrm{M}=3.63, \mathrm{SD}=1.05)$ of the geography teachers indicated that they choose appropriate information technologies to optimize geography teaching. Teachers were also confident that they could use information technologies to improve classroom interaction $(\mathrm{M}=3.88, \mathrm{SD}=1.07)$. In terms of using information technologies to enhance students' enthusiasm for learning, the geography teachers seem to have demonstrated comparatively greater confidence $(\mathrm{M}=4.35$, $\mathrm{SD}=0.87$ ) with the spread of their responses close.

Further on TPK, the dominant part $(\mathrm{M}=3.93, \mathrm{SD}=1.27)$ of the teachers indicated that they can use information technologies to engage students to actively participate in classroom activities. Teachers were also confident about their awareness of the critical role information technologies play in classroom teaching. The dominant part $(\mathrm{M}=3.99$, SD $=1.10$ ) of the teachers indicated that they can adaptively use information technologies in various teaching activities, however, the spread of their responses is quite wide. Lastly, on teachers' TPK, the dominant part $(\mathrm{M}=3.79$, SD = 1.24) of the teachers was confident in selecting appropriate information technologies to optimize geography teaching. This finding supports the teachers' assertion that they know about different technologies. Knowledge of different technologies, as the teachers asserted, is likely to help them select the appropriate technologies to optimize their classroom teaching.

\subsection{Geography teachers' rating of their understanding of Technological Pedagogical Content Knowledge (TPACK)}

This represents knowledge about the complex relationship that exists among the three main facets of teacher knowledge, that is, content knowledge, pedagogical knowledge and technological knowledge. Comparatively, the mean scores of teachers for the items under the TPACK construct were generally the lowest with mean scores ranging from 3.06 to 3.61. Table 4 depicts the mean scores for teachers' TPACK.

The results in Table 4 show that the majority $(M=3.61, S D=1.19)$ of the geography teachers can plan activities according to the geography curriculum, and help students apply proper information technologies to construct various representations of content knowledge ( 3.33 , $\mathrm{SD}=1.09$ ) of the teachers demonstrated some level of ability to design lessons that integrate proper geography subject contents, information technologies and pedagogical methods, following the student-centered teaching philosophy. However, the teachers had low confidence in terms of their ability to design Information Technologysupported autonomous learning activities for specific geography subject content (such as the use of blogging, online searching, etc.). This finding raises a question about how helpful the teachers could be to their students during the era of shutdowns with respect to the coronavirus pandemic outbreak, where students were required to learn from home via 
virtual platforms. Among the other items under the TPACK construct, the item "I can design and assign geographic topics relevant discussion activities and promote collaborative learning among students via appropriate information technologies" recorded the lowest mean $(\mathrm{M}=3.06, \mathrm{SD}=1.19)$.

Table 4. Technological Pedagogical Content Knowledge of geography teachers

\begin{tabular}{|c|c|c|}
\hline Statement & Mean & SD \\
\hline $\begin{array}{l}\text { I can plan activities according to the geography curriculum, and help students apply } \\
\text { proper information technologies to construct various representations of content knowledge } \\
\text { (such as the use of mind-mapping, Wikipedia, etc.) }\end{array}$ & 3.61 & 1.19 \\
\hline $\begin{array}{l}\text { I can design Information Technology-supported autonomous learning activities } \\
\text { for specific geography course content } \\
\text { (such as the use of blogging, online searching, etc.) }\end{array}$ & 3.06 & 1.38 \\
\hline $\begin{array}{l}\text { I can design inquiry-based activities, and apply appropriate information technologies to } \\
\text { facilitate students' understanding of geography course content }\end{array}$ & 3.15 & 1.21 \\
\hline $\begin{array}{l}\text { I can design lessons that integrate proper geography subject contents, } \\
\text { information technologies and pedagogical methods, } \\
\text { following the student-centered teaching philosophy }\end{array}$ & 3.25 & 1.09 \\
\hline $\begin{array}{l}\text { I can design and assign geographic topics relevant to discussion activities } \\
\text { and promote collaborative learning among students via appropriate information technologies }\end{array}$ & 3.33 & 1.31 \\
\hline
\end{tabular}

Source: Field data (2020)

\section{Discussion}

The teachers' mean scores on the three technological constructs (technological pedagogical knowledge, technological content knowledge, and technological pedagogical content knowledge) were relatively low. This finding indicates that the geography teachers' level of knowledge in terms of blending content and pedagogy with technology is quite low. The implication is that there is more to do in the area of teaching with technologies. These geography teachers need to develop their competencies in the pedagogical and educational use of technologies (Uerz et al., 2018). This finding of the present study contradicts what Apau (2017) found about pre-service teachers, where it was reported that they exhibited a high level of technological knowledge. This contradiction may have arisen from the fact that preservice teachers' perceived knowledge about technology becomes less practical when they get into the classroom. For instance, Uerz et al. (2018) stressed that self-reporting competencies stand at the risk of being distorted from reality by either overestimation or underestimation. This assertion is further supported by Akyuz (2018), Krauskopf and Forssell (2018), and Kopcha et al. (2020) who argue that self-reporting TPACK tends to show no correspondence with more objective measures. With most TPACK studies focusing on pre-service teachers (Schmid et al., 2021; Valtonen et al., 2020; Wright, \& Akgunduz, 2018; Valtonen et al., 2017; Apau, 2017), it is important that future studies need to involve in-service teachers to validate the finding.

Comparatively, the average score of the teachers in TPK was higher than that in TCK. Like Hill and Uribe-Florez's (2020) study, this finding is also contrary to Cox's (2008) suggestion that secondary teachers' TCK is higher than their TPK. At least, another recent study conducted by Nuangchalerm (2020) gives credence to the claim that teachers possess higher TPK compared to TCK. As suggested by Hill and Uribe-Florez (2020), more research involving TCK and TPK would provide evidence to back up any such assertions. However, our finding is consistent with the policy guidelines for the teaching and learning of geography in senior high schools in Ghana as pointed out by Ababio and Dumba (2014). According to the policy, senior high school geography teachers in Ghana must possess, in addition to content knowledge of geography, high proficiency in blending pedagogy with content. Thus, for a topic to be effectively taught, the teacher must be able to employ the appropriate pedagogic procedures for teaching it to specific types of students (Ababio \& Dumba, 2014). 
Out of the three constructs used for this study, teachers' rating on the Technological Pedagogical Content Knowledge (TPACK) was considered very critical by the researchers. This is because Mishra and Koehler (2006) describe knowledge of TPACK as the basis of good teaching in the $21^{\text {st }}$ century. Thus, teachers in their quest to impart knowledge should possess the skill of integrating technological, pedagogic and content knowledge into the right mix for selecting content, planning strategies, and selecting appropriate tools for classroom activities while bearing in mind the context. Meanwhile, it was the TPACK that recorded the lowest mean score (at 3.28) among the three constructs. This finding gives credence to what Hill and Uribe-Florez (2020) reported on mathematics teachers where the teachers had the least competence in giving classes that properly mix algebra, technologies, and teaching methodologies, with a 3.68 average score. Based on the mean scores for TPACK, it is clear that geography teachers need professional development training to be able to integrate technologies into instructions to achieve expected educational goals in this contemporary era as asserted by Bingimlas (2009). This is also important because Yelland (2001) argues that institutions that are not integrating new technologies offered by ICT cannot significantly claim to adequately prepare their students for real life in the $21^{\text {st }}$ century.

Much of the problem of technological literacy and its use in teaching and learning among in-service teachers can be linked to the competencies of teacher educators (Uerz et al., 2018). The researchers, therefore, perceive that most teacher educators in higher institutions for teacher training are doing little in applying technology to their own teaching. Although Afari-Kumah and Tanye (2009) observed that there was some improvement seen in the area of educational use of technology in tertiary institutions, authors could only point to the use of online courses and e-resources. Teacher educators are expected to develop four domains of competencies for teaching with technology in order to foster the same in student-teachers: technology competencies, competencies in the pedagogical and educational use of technology, beliefs about teaching and learning, and competencies in innovation and professional learning (Uerz et al., 2018).

\section{Conclusion and recommendations}

This study assessed senior high school geography teachers' TPACK in the teaching and learning of geography. It can be concluded from the study that geography teachers are professionally confident given their adequate knowledge about the subject matter of geography and their knowledge of the instructional techniques and methods appropriate for teaching the subject. The teachers acknowledged the interconnections existing between the various facets of teacher knowledge needed to effectively teach in the classroom. However, geography teachers have more room for improvement in terms of keeping abreast with emerging technologies and understanding their relevance in the teaching and learning process. Even though they accept technology as an integral part of classroom instruction, they lack sufficient technical knowledge to be able to integrate it into their lessons.

The outcome of the study has shown implications for professional teacher training and curriculum revision. As the finding of the study has suggested, in professional teacher preparation and training, higher institutions should ensure the teaching of the content and pedagogy of geography in an integrated manner and should not be treated as isolated knowledge areas. In addition to this, pre-service geography teachers should be taught how to integrate new technologies into the teaching and learning of geography. This should not be a mere exposure of students to general ICT courses; rather, ICT courses should be tailored to the teaching and learning needs of geography. Thus, pre-service teachers should be trained on how to integrate some specific technologies that enhance geographic studies. In addition, teacher educators at higher educational levels should integrate ICTs into their own teaching to help future teachers appreciate the place of specific technologies, hardware and software, in the teaching and learning of their respective disciplines.

Based on the outcome of the study, the following recommendations are made: Professional teacher training institutions should structure their programmes in such a way that ICT would not just be taught as an isolated course. Instead, ICT courses should be tailored to the individual disciplinary needs to help students appreciate the place of specific technologies, hardware and software, in their disciplines of study. The National Council for Curriculum and Assessment (NaCCA) should collaborate with experts in the higher institutions to revise the geography syllabus, clarifying the place of specific technologies in the teaching and learning of specific aspects of the geography content. The Ghana Education Service should provide teachers with continuous professional development training in the form of workshops to update teachers' knowledge and develop their skills in the use of technologies in classroom teaching. By 
way of improving teachers' competencies in technology integration into classroom teaching, Ghana Education Service may advise every teacher to obtain a diploma in ICT.

\section{Acknowledgement}

The authors would like to thank all the anonymous respondents who provided data to help complete this study. Authors whose works were drawn for the analysis are duly acknowledged. We also wish to extend our appreciation to the Editors of this journal for providing the platform to share academic knowledge for the global scholarship. The anonymous reviewers of this paper are well-appreciated.

\section{Conflict of interest}

The authors declare no competing financial interest.

\section{References}

Ababio, B., T., \& Dumba, H. (2014). Assessment of the policy guidelines for the teaching and learning of geography at the senior high school level in Ghana. Review of International Geographical Education Online, 4(1), 40-57.

Afari-Kumah, E., \& Tanye, H. A. (2009). Tertiary students' view on information and communications technology usage in Ghana. Journal of Information Technology Impact, 9(2), 81-90.

Agyei, D. D. (2013). Analysis of technology integration in teacher education in Ghana. Journal of Global Initiatives: Policy, Pedagogy, Perspective, 8(1), 69-74.

Akyuz, D. (2018). Measuring Technological Pedagogical Content Knowledge (TPACK) through performance assessment. Computers \& Education, 125, 212-225. https://doi. org/10.1016/j.compedu.2018.06.012

Amedzo, E. K. (2007). The integration of information and communications technology into rural schools of South Africa: A case study of schools in Malamulele (Unpublished. Thesis). Stellenbosch University.

Amenyedzi, F. W. K., Lartey, M. N., \& Dzomeku, B. D. (2011). The use of computers and internet as supplementary source of educational material: A case study of the senior high schools in the Tema metropolis in Ghana. Contemporary Educational Technology, 2(2), 151-162.

Antwi, S., Bansah, A., K., \& Franklin, T. (2018). The information technology challenge in teaching senior high school geography in Ghana. Issues and Trends in Learning Technology, 6(1). https://doi.org/10.2458/azu_itet_v6i1_antwi

Apau, S. K. (2017). Technological pedagogical content knowledge preparedness of student-teachers of the Department of Arts and Social Sciences Education of University of Cape Coast. Journal of Education and Practice, 8(10), 167181.

Bingimlas, K. A. (2009). Barriers to the successful integration of ICT in teaching and learning: A review of literature. Journal of Creative Education, 5(3), 235-245. https://doi.org/10.12973/ejmste/75275

Boadu, G., Awuah, M., Ababio, A. M., \& Eduaquah, S. (2014). An examination of the use of technology in the teaching of history: a study of selected senior high schools in the Cape Coast Metropolis, Ghana. International Journal of Learning, Teaching and Educational Research, 8(1), 187-214.

Bolarinwa, O. A. (2015). Principles and methods of validity and reliability testing of questionnaires used in social and health science researches. Niger Postgraduate Medical Journal, 22(4), 195-201. https://doi.org/10.4103/11171936.173959

Cohen, L., Manion, L., \& Morrison, K. (2007). Research Methods in Education (6th ed.). London: Routledge.

Cox, S. M. (2008). A conceptual analysis of technological pedagogical content knowledge. Unpublished doctoral dissertation. Provo, UT: Brigham Young University.

Earle, R. (2002). The integration of instructional technology into public education: promises and challenges. Educational Technology, 42(1), 5-13.

Fatima, M. (2016, March 22). Perceptions of Geography as a discipline among students of different academic levels in Pakistan. Review of International Geographical Education Online (RIGEO), 6(1), 67-85. https://www.rigeo.org/ vol6/Number1Spring/RIGEO-V6-N1.pdf 
Geographical Association (2004). ICT in geography in secondary schools: a survey. Teaching Geography, 29(1), 39-41. Ghana Education Fact Sheets (2020). Analyses for learning and equity using MICS data. Unicef Ghana.

Gray, D. E. (2004). Doing Research in the Real World. London: Sage.

Hill, J. E. \& Uribe-Florez, L. (2020). Understanding secondary school teachers' TPACK and technology implementation in mathematics classrooms. International Journal of Technology in Education (IJTE), 3(1), 1-13. https://doi. org/10.46328/ijte.v3i1.8

Kereluik, K., Mishra, P., \& Koehler, M. J. (2011). On learning to subvert signs: Literacy, technology and the TPACK framework. California Reader, 44(2), 12-18.

Kocalar, A. O., \& Demirkaya, H. (2017, December 19). Geography teachers' views on effective geography teaching. Review of International Geographical Education Online (RIGEO), 7(3), 332-346. http://www.rigeo.org/vol7no3/ Number3Winter/RIGEO-V7-N35.pdf

Koehler, M. J., \& Mishra, P. (2005). What happens when teachers design educational technology? The development of technological pedagogical content knowledge. Journal of Educational Computing Research, 32(2), 131-152. https://doi.org/10.2190/0EW7-01WB-BKHL-QDYV

Koehler, M. J., \& Mishra, P. (2008). Introducing TPCK. In J. A. Colbert, K. E. Boyd, K. A. Clark, S. Guan, J. B. Harris, M. A. Kelly \& A. D. Thompson (Eds.), Handbook of Technological Pedagogical Content Knowledge (TPCK) for Educators (pp. 3-30). New York: Routledge.

Kopcha, T. J., Neumann, K. L., Ottenbreit-Leftwich, A., \& Pitman, E. (2020). Process over product: The next evolution of our quest for technology integration. Educational Technology Research and Development, 68(2), 729-749. https://doi.org/10.1007/s11423-020-09735-y

Krauskopf, K., \& Forssell, K. (2018). When knowing is believing: A multi-trait analysis of self-reported TPCK. Journal of Computer Assisted Learning, 34(5), 482-491. https://doi.org/10.1111/jcal.12253

Mereku, D. K., Yidana, I., Hordzi, W., Tete-Mensah, I., Tete-Mensah, W., \& Williams, J. B. (2009). Pan African research agenda on the pedagogical integration of ICTs: Ghana report. https://www.ernwaca.org/panaf/pdf/ phase-1/GhanaPanAf_Report.pdf

McIntyre, L. J. (1999). The Practical Skeptic: Core Concepts in Sociology (pp. 75). Mountain View, CA: Mayfield Publishing.

Mishra, P., \& Koehler, M. J. (2006). Technological pedagogical content knowledge: A framework for teacher knowledge. Teachers College Record, 108(6), 1017-1054.

Niess, M. L. (2005). Preparing teachers to teach science and mathematics with technology: Developing a technology pedagogical content knowledge. Teaching and Teacher Education, 21(5), 509-523. https://doi.org/10.1016/ j.tate.2005.03.006

Nuangchalerm, P. (2020). TPACK in ASEAN perspectives: Case study on Thai pre-service teacher. International Journal of Evaluation and Research in Education (IJERE), 9(4), 993-999. https://doi.org/10.11591/ijere.v9i4.20700

Opoku, F. (2019). Perceptions of geography among Ghanaian senior high school students: A phenomenological study. International Journal of Geography and Geography Education, 39, 1-9. https://doi.org/10.32003/IGGEI.467488

Sarantakos, S. (2013). Social Research (4th ed.). London: Palgrave Macmillan.

Schmid, M., Brianza, E., \& Petko, D. (2021). Self-reported Technological Pedagogical Content Knowledge (TPACK) of pre-service teachers in relation to digital technology use in lesson plans. Computers in Human Behavior, 115, 1-12. https://doi.org/10.1016/j.chb.2020.106586

Su, X., Huang, X., Zhou, C., \& Chang, M. (2017). A Technological Pedagogical Content Knowledge (TPACK) scale for geography teachers in Senior High School. Education and Science, 42(190), 325-341. https://doi.org/10.15390/ EB.2017.6849

Uerz, D., Volman, M., \& Kral, M. (2018). Teacher educators' competences in fostering student teachers' proficiency in teaching and learning with technology: An overview of relevant research literature. Teaching and Teacher Education, 70, 12-23. https://doi.org/10.1016/j.tate.2017.11.005

Voogt, J. (2010).Teacher factors associated with innovative curriculum goals and pedagogical practices: differences between extensive and non-extensive ICT using science teachers. Journal of Computer Assisted Learning, 26, 453464. https://doi.org/10.1111/j.1365-2729.2010.00373.x

Valtonen, T., Leppänen, U., Hyypiä, M., Sointu, E., Smits, A., \& Tondeur, J. (2020). Fresh perspectives on TPACK: Pre-service teachers' own appraisal of their challenging and confident TPACK areas. Education and Information Technologies, 25, 2823-2842. Advance online publication. https://doi.org/ 10.1007/s10639-019-10092-4

Valtonen, T., Sointu, E., Kukkonen, J., Kontkanen, S., Lambert, M. C., \& MäkitaloSiegl, K. (2017). TPACK updated to measure pre-service teachers' twenty-first century skills. Australasian Journal of Educational Technology, 33(3), 
15-31. https://doi.org/10.14742/ajet.3518

Wright, B., \& Akgunduz, D. (2018). The relationship between Technological Pedagogical Content Knowledge (TPACK) self-efficacy belief levels and the usage of Web 2.0 applications of pre-service science teachers. World Journal on Educational Technology, 10(1), 52-69.

Yelland, N. (2001). Teaching and Learning with information and communication technologies (ICT) for numeracy in the early childhood and primary years of schooling. Australia: Department of Education, Training and Youth Affairs. 